\title{
Essential Nutrients for Bone Health and a Review of their Availability in the Average North American Diet
}

\author{
Charles T. Price*, Joshua R. Langford and Frank A. Liporace \\ Orlando Health, 1222 Orange Avenue, $5^{\text {th }}$ Floor, Orlando, Florida 32806, USA
}

\begin{abstract}
Osteoporosis and low bone mineral density affect millions of Americans. The majority of adults in North America have insufficient intake of vitamin D and calcium along with inadequate exercise. Physicians are aware that vitamin $\mathrm{D}$, calcium and exercise are essential for maintenance of bone health. Physicians are less likely to be aware that dietary insufficiencies of magnesium, silicon, Vitamin K, and boron are also widely prevalent, and each of these essential nutrients is an important contributor to bone health. In addition, specific nutritional factors may improve calcium metabolism and bone formation. It is the authors' opinion that nutritional supplements should attempt to provide ample, but not excessive, amounts of factors that are frequently insufficient in the typical American diet.

In contrast to dietary insufficiencies, several nutrients that support bone health are readily available in the average American diet. These include zinc, manganese, and copper which may have adverse effects at higher levels of intake. Some multivitamins and bone support products provide additional quantities of nutrients that may be unnecessary or potentially harmful.

The purpose of this paper is to identify specific nutritional components of bone health, the effects on bone, the level of availability in the average American diet, and the implications of supplementation for each nutritional component. A summary of recommended dietary supplementation is included.
\end{abstract}

Keywords: Osteoporosis, Nutrition, Vitamin D, Calcium, Bone.

\section{INTRODUCTION}

Approximately ten million Americans over the age of fifty have osteoporosis and another 34 million have low bone mass [1]. After the age of 50 years, a woman's risk of dying from a hip fracture is equal to her lifetime risk of dying from breast cancer $[2,3]$. Almost one out of five patients with a hip fracture dies within six months and one out of four dies within a year $[3,4]$. Many of these deaths are related to the immobility and increased metabolic demands caused by the fracture. Even though survival rates have improved in the first few weeks after a hip fracture, the one-year death rates have not improved over the last 40 years [4]. When patients survive more than a year, they are at increased risk for fracture of the opposite hip with subsequent morbidity and mortality. The limited mobility, and increased metabolic demand required to heal the injured hip contribute to weakening of the opposite hip. In the year following a hip fracture the loss of bone mineral density in the opposite hip is five times greater than expected bone loss in women who do not have a hip fracture [5]. Also, a younger age at time of the first fracture increases the risk of a second fracture [3].

Healthy nutritional habits combined with exercise should be encouraged to maintain bone health [1]. However, dietary supplementation with calcium and vitamin D is recommended for postmenopausal women to decrease the risk of fracture [6]. Additional management for osteopenia or

*Address correspondence to this author at the Orlando Health, 1222 Orange Avenue, 5th Floor, Orlando, Florida 32806, USA; Tel: 321.843.5271; Fax: 321.843.5298; E-mail: charles.price@orlandohealth.com osteoporosis may include medications, lifestyle changes, home safety modifications, hip protectors, and fall prevention. The purpose of this review is to identify several essential nutrients for bone health and compare the recommended intake to the dietary intake from the average North American diet. The role of exercise will also be identified as an important and frequently insufficient factor for bone health.

\section{VITAMIN D, CALCIUM, AND EXERCISE}

There is increasing recognition that insufficient exercise, poor vitamin $\mathrm{D}$ levels and low dietary calcium are common in modern society. Approximately $70 \%$ of children in the USA are insufficient or deficient in Vitamin D [7]. Similar prevalence of vitamin D insufficiency has been reported in adults. Dietary sources of vitamin D include oily fish such as salmon and swordfish, with lesser amounts in tuna and other fish. It is difficult to consume sufficient amounts of vitamin $\mathrm{D}$ from dietary sources alone. The average adult American diet only contains $150-300$ IU of Vitamin D per day [8]. Recommended dietary allowance of Vitamin D for adults is 600-800 IU per day, but higher levels may be optimal [9, 10]. A 2005 meta-analysis published in the Journal of the American Medical Association reported that supplements in the range of 700-800 IU/day decreased the risk of fractures, but doses of $400 \mathrm{IU} /$ day were not as effective [11]. The Endocrine society recommends $1500-2000$ IU of daily vitamin $\mathrm{D}$, and current research suggests that supplemental vitamin $\mathrm{D}$ is associated with decreases in mortality $[9,10$, $12,13]$. Therefore, supplementation with 400 IU to 1,000 IU of vitamin D per day is reasonable for the majority of healthy Americans. 
Calcium intake is also low for most age groups in the United States. The principal dietary source of calcium is milk and milk products although lesser sources include salmon, almonds, and leafy green vegetables such as spinach, kale, and turnip greens. The recommended dietary allowance of calcium is $1,200 \mathrm{mg}$ /day but the majority of women older than forty consume less than $600 \mathrm{mg}$ /day in the United States [14]. The average dietary calcium intake is below the recommended amount for $60-70 \%$ of teenage girls and for $70 \%$ of post-menopausal women [15]. Low calcium intake correlates with increased risk of hip fracture, but increasing intake above $750 \mathrm{mg} /$ day does not correlate with progressively lower risks of hip fracture [16-18]. There may be additional health benefits from slightly higher levels of calcium intake, so an appropriate supplementary dose is 400$800 \mathrm{mg} /$ day in order to achieve $1,2000 \mathrm{mg} /$ day as recommended by the National Institutes of Health [14, 19]. Very high levels of calcium supplementation have been associated with increased risks of kidney stones and myocardial infarction $[19,20]$. Therefore, calcium supplementation should achieve the recommended dietary allowance without providing excessive amounts.

Modest exercise is also essential for general health and for bone health. Approximately $40 \%$ of adults do not participate in leisure time physical activity [21]. A 2005 report from the Centers for Disease Control and Prevention noted that two thirds of high school students were below national standards for moderate physical activity [22]. Just 15 minutes of modest exercise a day can significantly prolong life and decrease the risk of cancer and other diseases [23]. Only 20 minutes of modest impact activity, resistance training, or vibration therapy three times a week can improve bone mineral density [2, 24]. Exercise also decreases the risk of falls by improving muscle tone, balance and coordination [25]. Therefore, modest exercise should also be recommended as part of a bone health program.

\section{LESSER KNOWN NUTRITIONAL NEEDS}

What is less known to practicing physicians is that several other vitamins and minerals are associated with improved bone strength independent of vitamin D and calcium. As stated by Munger, et al., "The preoccupation to date with calcium has resulted in less emphasis on the role of other nutrients in bone quality and osteoporosis [16]." Examples of common insufficiencies in addition to Vitamin $\mathrm{D}$ and calcium are magnesium, silicon, vitamin $\mathrm{K}$, and boron. (Table 1) [26-30]

Magnesium is increasingly recognized as an important contributor to bone health [31-33]. A study of women with osteoporosis in Israel reported significantly increased bone mineral density with $250 \mathrm{mg} /$ day of magnesium supplement when compared to a control group who did not take magnesium supplements [34]. Dietary sources of magnesium include almonds, cashews and peanuts. Other sources include raisin bran cereal, potato skins, brown rice, kidney beans, black-eyed peas and lentils. Eight ounces of milk has approximately $25 \mathrm{mg}$ of magnesium. The recommended dietary allowance for optimum health is $320-420 \mathrm{mg}$ [35]. However, more than half of the US population consumes less than $245 \mathrm{mg}$ per day [28]. Thus modest supplementation with $250 \mathrm{mg}$ /day of magnesium is reasonable to support bone health, and for other aspects of general health [32].

Silicon is another important contributor to bone health [36-38]. Silicon is an essential nutrient and silicon deficiency is associated with poor skeletal development [37, 39]. Carlisle performed electron probe microanalyses of various regions of bone and determined that silicon is twenty-five times more concentrated in immature osteoid than in mature bone [40]. Carlisle concluded that silicon plays a role in the initiation of the mineralization process. It is also known that silicon is used in micro-pressure transducers and in the computer electronics industry because of silicon's unique piezoresistive properties as a semi-conductor element [41]. The relationship between silicon and bone mineralization is poorly understood, but negative piezoelectric forces are generated and stimulate bone formation when collagen matrix is subjected to compression $[42,43]$. Epidemiological studies report that dietary silicon intake of more than 40 $\mathrm{mg}$ /day correlates with increased bone mineral density, but the average dietary intake of silicon is $20-30 \mathrm{mg} /$ day [ 29 , 44]. Dietary sources of silicon include whole grains and cereals, carrots and green beans [45]. Some types of mineral

Table 1. Common Nutrients for Bone Health

\begin{tabular}{|c|c|c|c|}
\hline Nutrient & Recommended Dietary Allowance & Median Intake & Authors' Preferred Supplementation \\
\hline \hline Vitamin D & $600-800 \mathrm{IU}$ & $150-300 \mathrm{IU}$ & $400-1000 \mathrm{IU}$ \\
\hline Calcium & $1000-1200 \mathrm{mg}$ & $735 \mathrm{mg}$ & $500 \mathrm{mg}$ \\
\hline Magnesium & $320-420 \mathrm{mg}$ & $243 \mathrm{mg}$ & $250-350 \mathrm{mg}$ \\
\hline Silicon & $* 40 \mathrm{mg}$ for bone health & $21 \mathrm{mg}$ & $20-40 \mathrm{mg}$ \\
\hline Vitamin K & $90-120 \mu \mathrm{gm}$ & $70-80 \mu \mathrm{gm}$ & $50-150 \mu \mathrm{gm}$ \\
\hline Boron & $* 3 \mathrm{mg}$ for bone health & $1 \mathrm{mg}$ & $1-3 \mathrm{mg}$ \\
\hline Vitamin C & $75-90 \mathrm{mg}$ & $103 \mathrm{mg}$ & $50-100 \mathrm{mg}$ \\
\hline Copper & $0.9 \mathrm{mg}$ & $9.6 \mathrm{mg}$ & None \\
\hline Zinc & $8-11 \mathrm{mg}$ & $2.8 \mathrm{mg}$ & None unless vegetarian or elderly \\
\hline Manganese & $1.8-2.3 \mathrm{mg}$ & & None \\
\hline
\end{tabular}


water also contain silicon in the form of orthosilicic acid [46]. Beer is a rich source of silicon because of the processing of barley and hops [47]. Men consume more silicon them women and this is primarily due to differences in beer consumption [45]. Post-menopausal women rarely achieve $40 \mathrm{mg}$ of silicon per day and average approximately $18 \mathrm{mg}$ per day [29, 48]. Also, post-menopausal women may not absorb silicon as well as younger women. Thus, silicon supplementation with approximately 20-30 mg/day may benefit bone health for the majority of Americans who do not consume beer on a regular basis.

Vitamin $\mathrm{K}$ is another lesser known nutrient that is important for bone health. Vitamin $\mathrm{K}$ has several different forms, but vitamin $\mathrm{K}_{1}$ and $\mathrm{K}_{2}$ are the naturally occurring forms [49]. The name for this vitamin comes from the German word "Koagulationsvitamin" because it is essential for coagulation of blood. Excessive vitamin $\mathrm{K}$ does not increase the risk of blood clots, but those taking warfarin (Coumadin $^{\circledR}$ ) for anti-coagulation should avoid supplemental vitamin $\mathrm{K}$ because warfarin is a vitamin $\mathrm{K}$ antagonist [28, 49]. Insufficient vitamin $\mathrm{K}$ is associated with undercarboxylation of osteocalcin, osteopenia and increased fracture risk, while vitamin $\mathrm{K}$ supplementation reduces bone turnover and improves bone strength [28, 49]. Useful dietary sources of vitamin $\mathrm{K}$ include kale, collard greens, fresh spinach, Brussels sprouts, iceberg lettuce, and prunes. The optimum daily intake of vitamin $\mathrm{K}$ has been established as $90 \mu \mathrm{gm}$ (micrograms) per day for women and $120 \mu \mathrm{gm}$ per day for men. However, larger amounts may be needed for complete carboxylation of osteocalcin [28]. According to the Third National Health and Nutrition Examination Survey, approximately half of the men and women in the United States consume less than the recommended amount of vitamin $\mathrm{K}$, and one quarter of the population consumes less than $60 \mu \mathrm{gm}$ per day [28] In a study of hip fracture risk, women who consumed more than $109 \mu \mathrm{gm}$ of vitamin $\mathrm{K}$ per day had an decreased risk of hip fracture compared to women with lower levels of vitamin $\mathrm{K}$ intake [50]. Vitamin $\mathrm{K}_{2}$ has been administered in pharmacological doses for osteoporosis treatment in Japan with doses ranging from 15 $\mathrm{mg}$ /day to $135 \mathrm{mg}$ /day (over 1,000 times the recommended daily allowance) [51]. Doses of $45 \mathrm{mg} /$ day have decreased fracture rates $37 \%$ which is similar to fracture decreases following treatment with bisphosphonates. However, lower fracture rates from vitamin $\mathrm{K}$ supplementation are not accompanied by increased bone mineral density [51, 52]. This suggests that vitamin $\mathrm{K}$ improves bone properties that increase bone strength without increasing mineral content. Vitamin $\mathrm{K}$ has no toxicity except for those using warfarin, so supplementation with $100 \mu \mathrm{gm} /$ day would to achieve slightly more than the recommended daily allowance and may have beneficial effects on bone structure.

Boron is increasingly recognized as an element that has several health benefits including bone health [53-55]. Boron is a semi-conductor with the atomic number of 5 . The precise mechanism of action of boron for bone health is unknown, but boron stabilizes and extends the half-life of vitamin D and estrogen [28, 53, 54]. Approximately half the population in the United States consumes less than $1 \mathrm{mg}$ of Boron per day [28]. Supplementation with $3 \mathrm{mg}$. of boron per day for post-menopausal women has demonstrated improved calcium and magnesium retention by the kidneys
[56]. Increased bone strength has also been demonstrated in pigs fed a diet supplemented with boron [57]. Prunes are a rich source of boron with approximately 3-4 $\mathrm{mg}$ of boron for every three ounce serving of prunes [30]. A study of postmenopausal women reported that a 3-ounce serving of prunes daily for a period of one year improved bone mineral density but dried apples did not [58]. The Recommended Daily Allowance of boron has not been established, but no toxicity has not been identified and excess boron is rapidly excreted in the urine [28]. Thus, it is reasonable to supplement the diet with 1-3 mg of boron although this dietary need may also be met by increased consumption of foods such as prunes, raisins, dried apricots, or avocados.

These lesser known insufficiencies of magnesium, silicon, vitamin $\mathrm{K}$, and boron are rarely explained to physicians although the more common insufficiencies of calcium, vitamin $\mathrm{D}$ and exercise are increasingly recognized as contributors to bone health. In addition to these essential nutrients, vitamin $\mathrm{C}$, inositol and L-arginine have beneficial effects on bone health. These three nutrients have been correlated with increased bone mineral density and improved bone strength when provided in physiological amounts [59-64]. The actions of these three factors are to improve various aspects of the bone formation and remodeling as well as calcium absorption and retention. Vitamin $\mathrm{C}$ is essential for the formation of collagen and for fracture healing [65]. The evidence for supplemental vitamin $\mathrm{C}$ in the management of osteoporosis is weak, but increased bone mineral density has been noted in postmenopausal women taking vitamin $\mathrm{C}$ supplements $[63,66]$. Inositol is a carbohydrate compound found in cantaloupe, grapefruit, oranges, and prunes [67]. It is also found in the form of phytate in whole grains. Experimental studies using radioactive calcium have reported increased calcium uptake in bone in response to supplementation with myo-inositol [68]. Low phytate consumption has also been associated with osteoporosis in an epidemiological study [64]. L-arginine is a semi-essential amino acid and serves as a substrate for production of nitric oxide (NO) that improves endothelial function, reduces vascular resistance, promotes angiogenesis, and influences numerous metabolic processes [69, 70]. Experimental studies have determined that nitric oxide is released in response to mechanical stress on bone, and that blocking the release of nitric oxide interferes with fracture healing [71, 72]. Dietary arginine is available in dairy products, poultry, seafood, and meat in addition to nuts and oatmeal. There is some evidence that supplemental 1-arginine influences vascular relaxation and should not be used as a supplement following myocardial infarction, especially in patients older than 60 years at time of infarct [73, 74]. Studies where arginine, inositol, and silicon were taken together demonstrated increased bone mineral density and increased bone strength [61, 62, 75]. Mega-doses of these three supplements have been used without adverse effects as anti-oxidants (vitamin C), or to enhance sports performance (L-Arginine), or to improve psychiatric disorders (Inositol). However, mega-doses may not be required to influence bone health. Supplementing the diet with physiological amounts of these three nutrients may support bone health.

\section{QUESTIONABLE SUPPLEMENTS}

Some essential nutrients for bone health are readily available in the typical American diet. These include zinc, manganese, and copper. These nutrients are usually 
consumed in amounts that meet or exceed the recommended dietary allowance, so they should not need supplementation unless a disease state is present. Regardless of wide availability, these metals are frequently added to dietary supplements. It should be noted that high levels of supplementation with zinc, manganese and copper may have deleterious effects.

Table 2. Nutrient and Dietary Sources

\begin{tabular}{|c|c|}
\hline Nutrient and Dietary Sources & Content \\
\hline \multicolumn{2}{|l|}{ Calcium } \\
\hline $6 \mathrm{oz}$. calcium-fortified orange juice & $375 \mathrm{mg}$ \\
\hline $8 \mathrm{oz}$. milk or yogurt & $350 \mathrm{mg}$ \\
\hline $1.5 \mathrm{oz}$. cheddar or mozzarella cheese & $300 \mathrm{mg}$ \\
\hline $3 \mathrm{oz}$. canned salmon or sardines & $200 \mathrm{mg}$ \\
\hline $2 \mathrm{oz}$. almonds & $150 \mathrm{mg}$ \\
\hline 1 cup frozen yogurt, cream cheese, or cottage cheese & $125 \mathrm{mg}$ \\
\hline $1 / 2$ cup spinach, kale, bok choy, mustard or turnip greens & $100 \mathrm{mg}$ \\
\hline $1 / 2$ cup broccoli, green beans & $20 \mathrm{mg}$ \\
\hline \multicolumn{2}{|l|}{ Magnesium } \\
\hline 2 oz. almonds, cashews & $160 \mathrm{mg}$ \\
\hline $2 \mathrm{oz}$. peanuts, mixed nuts & $100 \mathrm{mg}$ \\
\hline 1 cup raisin bran, bran flakes, shredded wheat cereal & $75 \mathrm{mg}$ \\
\hline Medium baked potato with skin & $50 \mathrm{mg}$ \\
\hline $1 / 2$ cup brown rice, black-eyed peas, pinto/kidney beans, lentils & $35 \mathrm{mg}$ \\
\hline 8 oz. milk & $25 \mathrm{mg}$ \\
\hline \multicolumn{2}{|l|}{ Silicon } \\
\hline 16 oz. beer & $12 \mathrm{mg}$ \\
\hline 16 oz. FIJI® water & $45 \mathrm{mg}$ \\
\hline 16 oz. Volvic $\AA$ water & $15 \mathrm{mg}$ \\
\hline 1 serving whole grain cereal, granola, prunes, or apricots & $9 \mathrm{mg}$ \\
\hline $1 / 2$ cup brown rice, green beans & $4 \mathrm{mg}$ \\
\hline \multicolumn{2}{|l|}{ Boron } \\
\hline Small box raisins, $1 / 4$ cup prunes or almonds & $1 \mathrm{mg}$ \\
\hline $1 / 3$ cup peanuts or apricots & $1 \mathrm{mg}$ \\
\hline $1 / 2$ avocado & $1 \mathrm{mg}$ \\
\hline \multicolumn{2}{|l|}{ L-arginine } \\
\hline 3 oz chicken, turkey, beef, or pork & $2.0 \mathrm{gm}$ \\
\hline 3 oz. salmon or shrimp & $1.1 \mathrm{gm}$ \\
\hline $1 / 4$ cup peanuts & $1.0 \mathrm{gm}$ \\
\hline $1 / 4$ cup almonds, cashews, or 1 egg & $0.75 \mathrm{gm}$ \\
\hline
\end{tabular}

The Recommended Daily Allowance of zinc for men is $11 \mathrm{mg} /$ day and for women is $8 \mathrm{mg} /$ day. The average intake from dietary sources is $14 \mathrm{mg}$ /day for men and $9 \mathrm{mg}$ /day for women [28]. Therefore, supplementation is unnecessary for the typical American diet. Zinc is found in a wide variety of foods including red meat, lamb, shell fish, seeds, nuts, dairy products, poultry, and beans. Vegetarians and older

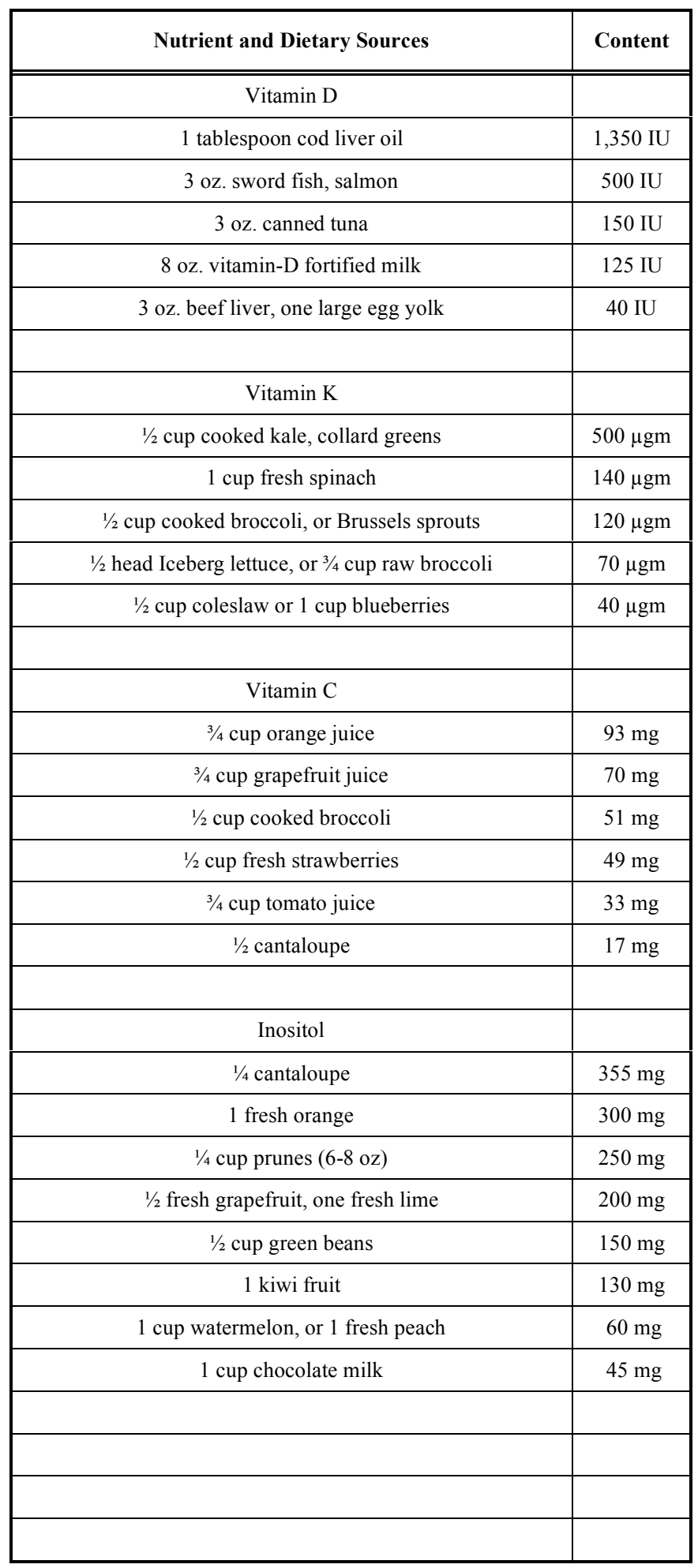


individuals may have insufficient zinc intake. After the age of 60 years approximately $35-45 \%$ of Americans have inadequate dietary zinc intake unless they are receiving some dietary supplementation [43]. Several popular multi-vitamins provide more than $15-30 \mathrm{mg}$ of zinc as a nutritional supplement even though the tolerable upper level recommended by the National Institutes of Health is 40 $\mathrm{mg}$ /day [76]. Long-term supplementation with more than 20 $\mathrm{mg}$ per day may be harmful unless the person is a vegetarian or malnourished [28, 77].

Manganese intake is also sufficient in the average American diet. The Recommended Daily Allowance is 1.8 $\mathrm{mg}$ /day for women and $2.3 \mathrm{mg} /$ day for men. Typical nonvegetarian Western diets provide $3 \mathrm{mg}$ to $7 \mathrm{mg}$ of manganese per day [28]. Dietary sources of manganese include cereals, nuts, pineapples, beans, mollusks (clams, oysters, mussels), dark chocolate, cinnamon, and tea. Excessive intake of manganese is associated with cognitive disorders in adults and children [78, 79]. When intake of iron and manganese are increased through supplementation, the risk of Parkinson's disease is doubled [80]. Consuming more than $11 \mathrm{mg} /$ day may have harmful effects according to the National Institutes of Health [28]. In spite of this information, some daily multi-vitamins provide $2-4 \mathrm{mg}$ of additional manganese.

The Recommended Daily Allowance of copper is 0.9 $\mathrm{mg}$ /day. However, dietary copper is available in a wide variety of foods including meats, seafood, nuts, grains, and cocoa products. The average American consumes 1.1-1.4 mg of copper per day and dietary copper insufficiency is rare in North America [28]. The National Academy of Sciences recommends that daily copper intake should be less than 10 $\mathrm{mg} /$ day [28].

\section{STRONTIUM}

Strontium is another nutritional supplement that should be questioned as a bone health product. Strontium is not an essential nutrient and it displaces calcium in bone [81]. Strontium has gained attention for bone mineralization in part because it increases bone density as measured by x-ray tests and DXA Scan $[82,83]$. However, this effect is partly caused by the strontium itself because strontium is a heavier element than calcium. Strontium is considered an alkaline earth metal with an atomic weight of 87.63. That makes it much heavier than calcium and it replaces natural calcium in bone. This gives the DXA scan a denser appearance because strontium absorbs the x-rays [83]. The x-ray absorbing properties of strontium gave rise to its use in early color television tubes so that $\mathrm{x}$-rays would be absorbed by the strontium and prevent irradiation of viewers [84]. Strontium ranelate in doses of $2 \mathrm{gm} /$ day have been used for the treatment of osteoporosis in several countries, but the United States Food and Drug Administration has not approved the use of strontium ranelate in the United States $[85,86]$. Oral intake of $2 \mathrm{gm} /$ day of strontium ranelate have improved bone strength and reduced fracture rates in women with osteoporosis, but there are reports of increased risks of venous blood clots and memory loss $[82,87]$. Strontium also accumulates in the body and remains there long term [82]. Therefore, strontium may need more evaluation before it becomes a routine treatment of osteoporosis.

\section{SUMMARY}

Nutritional needs for bone health can be met with proper food choices. (Table 2) However, supplementation of the average American diet is recommended for vitamin D, calcium, magnesium, silicon, vitamin $\mathrm{K}$, and boron. Regular exercise is also important for bone health. Modest amounts of zinc supplementation may be appropriate for vegetarians and for older individuals. However, routine supplementation with zinc, manganese, copper and other metals is generally unnecessary, and excessive supplementation may be harmful. Supplementation with strontium should also be questioned until long-term risks and benefits are better understood.

\section{ACKNOWLEDGEMENTS}

The authors thank Kenneth J. Koval, M.D., and George J. Haidukewych, M.D. for their review and comments prior to publication.

\section{CONFLICT OF INTEREST}

The authors are shareholders in the Institute for Better Bone Health, LLC, a nutritional supplement company.

\section{REFERENCES}

[1] U.S. Department of Health and Human Services. Bone Health and Osteoporosis: A Report of the Surgeon General. Rockville, MD: U.S. Department of Health and Human Services, Office of the Surgeon General, 2004.

[2] Chan K, Anderson M, Lau EMC. Exercise interventions: defusing the world's osteoporosis time bomb. Bull. World Health Organ 2003; 81(11): 827-30.

[3] Faucett S, Genuario JW, Tosteson ANA, Koval KJ. Is prophylactic fixation a cost-efficient method to prevent a future contralateral fragility hip fracture? J Orthop Trauma 2010; 24(2): 65-74.

[4] Haleem S, Lutchman L, Mayahi R. Mortality following hip fracture: trends and geographical variations over the last 40 years. Injury 2008; 39: 1157-63.

[5] Dirschl D, Henderson RC, Oakley WC. Accelerated bone mineral loss following a hip fracture: a prospective longitudinal follow-up. Bone 1997; 21(1): 79-82.

[6] Gehrig L, Lane J, O'Connor MI. Osteoporosis: management and treatment strategies for orthopedic surgeons. J Bone Joint Surg Am 2008; 90A: 1362-74.

[7] Kumar J, Muntner P, Kaskel FJ, Hauilpern SM, Melamed ML. Prevalence and associations of 20-hydroxyvitamin D deficiency in US children: NHANES 2001-2004. Pediatrics 2009; 124: e362-70.

[8] National Institutes of Health, Office of Dietary Supplements [Homepage on the Internet]. Vitamin D: Dietary supplement fact sheet for health professionals. Washington, DC [Updated: $24^{\text {th }}$ June 2011; Cited: 12 ${ }^{\text {th }}$ January 2012]. Available from: http://ods.od.nih. gov/factsheets/VitaminD-HealthProfessional/

[9] Heany $R$, The vitamin $D$ requirement in health and disease. J Steroid Biochem Mol Biol 2005; 97: 13-9.

[10] Holick M, Binkley NC, Bischoff-Ferrari HA, et al. Evaluation, treatment, and prevention of vitamin D deficiency: an endocrine society clinical practice guideline. J Clin Endocrinol Metab 2011; 96(7): 1911-30.

[11] Bischoff-Ferrari H, Willett WC, Wong JB, Giovannucci E, Dietrich T, Dawson-Hughes B. Fracture prevention with vitamin D supplementation: a meta-analysis of randomized controlled trials. JAMA 2005; 293: 2257-64.

[12] Bordelon P, Ghetu MV, Langan R. Recognition and management of vitamin D deficiency. Am Fam Physician 2009; 80(8): 841-6.

[13] Autier P, Gandini S. Vitamin D supplementation and total mortality. Arch Intern Med 2007; 167(16): 1730-7.

[14] National Institutes of Health, Office of Dietary Supplements [Homepage on the Internet]. Calcium: Dietary supplement fact sheet for health professionals. Washington DC [Updated: $31^{\text {st }}$ August 2011; Cited: $4^{\text {th }}$ January 2012]. Available from: http://ods. od.nih.gov/factsheets/calcium/ 
[15] Bailey R, Dodd KW, Goldman JA, et al. Estimation of total usual calcium and vitamin D intakes in the United States. J Nutr 2010; 140: 817-22.

[16] Munger R, Cerhan JR, Bhiu BC-H. Prospective study of dietary protein intake and risk of hip fracture in post-menopausal women. Am J Clin Nutr 1999; 69; 147-52.

[17] Bischoff-Ferrari H, Dawson-Hughes B, Baron JA, et al. Calcium intake and hip fracture risk in men and women: a meta-analysis of prospective cohort studies and randomized controlled trials. Am J Clin Nutr 2007; 86: 1780-90.

[18] Warensjo E, Byberg L, Melhus H, et al. Dietary calcium intake and risk of fracture and osteoporosis: prospective longitudinal cohort study. Br Med J 2011; 342: d1473.

[19] Celotti F, Bignamini A. Dietary calcium and mineral/vitamin supplementation: a controversial problem. J Int Med Res 1999; 27(1): 1-14.

[20] Bolland M, Grey A, Avenell A, Gambel GD, Reid IR. Calcium supplements with or without vitamin D and risk of cardiovascular events: reanalysis of Women's Health Initiative limited access dataset and meta-analysis. Br Med J 2011; 342(19): d2040.

[21] U.S. Department of Health and Human Services [Homepage on the Internet] Being physically active can help you attain or maintain a healthy weight. Office of the Surgeon General [cited 2012 Jan 20] Available from: http:/www.surgeongeneral.gov/topics/obesity/callt oaction/fact whatcanyoudo.html/

[22] Jones D, Hoelscher DM, Kelder SH, Hergenroeder A, Sharma SV Increasing physical activity and decreasing sedentary activity in adolescent girls - The Incorporating More Physical Activity and Calcium in Teens (IMPACT) study. Int J Behav Nutr Phys Act 2008; 5: 42-51.

[23] Wen C, Wai JP, Tsai MK, et al., Minimum amount of physical activity for reduced mortality and extended life expectancy: a prospective cohort study. Lancet 2011;378(9798): 1244-53.

[24] Merriman H, Jackson K. The effects of whole-body vibration training in aging adults: a systematic review. J Geriatr Phys Ther 2009; 32: 134-45.

[25] de Kam D, Smulders E, Weerdesteyn V, Smits-Engelsman BC. Exercise interventions to reduce fall-related fractures and their risk factors in individuals with low bone density: a systematic review of randomized controlled trials. Osteoporos Int 2009; 20(12): 201125.

[26] Ervin RB, Wang CY, Wright JD, Kennedy-Stephens J. Dietary intake of selected minerals for the United States population: 19992000. Advanced data from vital health statistics; no. 341. Hyattsville, Maryland: National Center for Health Statistics, 2004.

[27] Ervin R, Wang CY, Wright JD, Kennedy-Stephens J. Dietary intake of selected vitamins for the United States population: 19992000. Advanced data from vital health statistics; no. 399. Hyattsville, Maryland: National Center for Health Statistics, 2004.

[28] National Academy of Sciences. A Report of the Panel on Micronutrients. Dietary reference intakes for vitamin A, vitamin K, arsenic, boron, chromium, copper, iodine, iron, manganese, molybdenum, nickel, silicon, vanadium, and zinc. Washington DC: National Academy Press 2001.

[29] Jugdaosingh R, Tucker KL, Qiao N, Cupples LA, Kiel DP, Powell JJ. Dietary silicon intake is positively associated with bone mineral density in men and premenopausal women of the Framingham offspring cohort. J Bone Miner Res 2004; 19(2): 297-307.

[30] Hooshmand S, Arjmandi BH. Viewpoint: Dried plum, an emerging functional food that may effectively improve bone health. Ageing Res Rev 2009; 8: 122-7.

[31] Launius B, Brown PA, Cush EM, Mancini MC. Osteoporosis: the dynamic relationship between magnesium and bone mineral density in heart transplant patients. Crit Care Nurs Q 2004; 27(1): 96-100.

[32] Vormann J. Magnesium: nutrition and metabolism. Mol Aspects Med 2003. 24(1-3): 27-37.

[33] Rude R, Singer FR, Gruber HE. Skeletal and hormonal effects of magnesium deficiency. J Am Coll Nutr 2009; 28(2): 131-41.

[34] Stendig-Lindberg G, Tepper R, Leichter I. Trabecular bone density in a two year controlled trial of peroral magnesium in osteoporosis. Magnes Res 1993; 6(2): 155-63.

[35] National Institutes of Health, Office of Dietary Supplements [Homepage on the Internet]. Magnesium: Dietary supplement fact sheet for health professionals. Washington, DC [Updated: 13 July
2009; Cited: 18 January 2012]. Available from: http://ods.od.nih. gov/factsheets/magnesium/

[36] Jugdaohsingh R. Silicon and bone health. J Nutr Health Aging 2007; 11: 99-110.

[37] Carlisle EM. Silicon: a requirement in bone formation independend of Vitamin $\mathrm{D}_{1}$. Calcif Tissue Int 1981; 33: 27-34.

[38] Rico H, Gallego-Lago JL, Hernandez ER, et al. Effect of silicon supplement on osteopenia induced by ovariectomy in rats. Calcif Tissue Int 2000; 66: 53-5

[39] Nielsen F, Sandstead HH. Are nickel, vanadium, silicon, fluorine, and tin essential for man? A review. Am J Clin Nutr 1974; 27(5): 515-20.

[40] Carlisle EM. Silicon: a possible factor in bone calcification. Science 1970; 167: 179-80.

[41] Kanda Y. Piezpresistance effect of silicon. Sens Actuators 1991; A28(2): 83-91.

[42] Miclau T, Bozic KJ, Tay B, et al. Bone injury, regeneration, and repair. In: Einhorn TA, O'Keefe RJ, Buckwalter JA, Eds. Orthopedic basic science: foundations of clinical practice. Rosemont, IL: American Adacemy of Orthopedic Surgeons 2007; pp. 331-48.

[43] Noris-Suarez K, Lira-Olivares J, Ferrira AM, et al. In vitro deposition of hydroxyapatite on cortical bone collagen stimulated by deformation-induced piezoelectricity. Biomacromolecules 2007; 8(3): 941-8.

[44] Pennington J. Silicon in foods and diets. Food Addit Contam 1991; 8(1): 97-118.

[45] Jugdaosingh, R, Anderson SHC, Tucker KL, et al. Dietary silicon intake and absorption. Am J Clin Nutr 2002; 75: 887-93.

[46] Giammarioli S, Mosca M, Sanzini E. Silicon content of Italian mineral waters and its contribution to daily intake. J Food Sci 2005; 70: S509-12.

[47] Bellia J, Birchall JD, Roberts NB. Beer: a dietary sourde of silicon. Lancet 1994; 343: 235.

[48] McNaughton S, Bolton-Smith C, Mishra GD, Jugdaosingh R, Powell JJ. Dietary silicon intake in post-menopausal women. Br J Nutr 2005; 94: 813-7.

[49] Bügel S. Vitamin K and bone health in adult humans. In: Litwack G, Ed. Vitamins and Hormones: Vitamin K. London: Elsevier 2008; pp. 393-416.

[50] Feskanich D, Weber P, Willett WC, Rockett H, Booth SL, Colditz GA. Vitamin $\mathrm{K}$ intake and hip fractures in women: a prospective study. Am J Clin Nutr 1999; 69: 74-9.

[51] Iwamoto J, Takeda T, Sato Y. Menatetrenone (Vitamin K2) and bone quality in the treatment of postmenopausal osteoporosis. Nutr Rev 2006; 64(12): 509-17.

[52] Booth S, Tucker TL, Chen H, et al. Dietary vitamin K intakes are associated with hip fracture but not with bone mineral density in elderly men and women. Am J Clin Nutr 2000; 71(5): 1201-8.

[53] Penland J. Dietary boron, brain function, and cognitive performance. Environ Health Perspect 1994; 102(S7): S65-72.

[54] Volpe S, Taper LJ, Meacham S. The relationship between boron and magnesium status and bone mineral density in the human: a review. Magnes Res 1993; 6(3): 291-6.

[55] Newnham R. Essentiality of boron for healthy bones and joints. Environ Health Perspect 1994; 102S(S7): 83-95S.

[56] Nielsen F. Studies on the relationship between boron and magnesium which possibly affects the formation and maintenance of bones. Magnes Trace Elem 1990; 9(2): 61-9.

[57] Armstrong T, Spears JW, Crenshaw TD, Nielsen FH. Boron supplementation of a semipurified diet for weanling pigs improves feed efficiency and bone strength characteristics and alters plasma lipid metabolites. J Nutr 2000; 130(10): 2575-81.

[58] Hooshmand S, Chai SC, Saadat RL, Payton ME, Brummel-Smith $\mathrm{K}$, Arjmandi BH. Comparative effects of dried plum and dried apple on bone in postmenopausal women. Br J Nutr 2011; 106: 923-30.

[59] McCarty M. Supplemental arginine and high-dose folate may promote bone health by supporting the activity of endothelial-type nitric oxide synthase in bone. Med Hypotheses 2005; 64(5): 10303.

[60] Hall S, Greendale GA. The relation of dietary vitamin C intake to bone mineral density: results from the PEPI study. Calcif Tissue Int 1998; 63(3): 183-9. 
[61] Sahin K, Onderci M, Sahin T, et al. Dietary arginine silicate inositol complex improves bone mineralization in quail. Poult Sci 2006; 85: 486-92.

[62] Küçükbay F, Yazlak H, Sahin N, et al. Effects of dietary arginine silicate inositol complex on mineral status in rainbow trout (Oncorhynchus mykiss). Aquac Nutr 2008; 14(3): 257-62.

[63] Leveille S, LaCroix AZ, Koepsell TD, et al. Dietary vitamin C and bone mineral density in postmenopausal women in Washington State, USA. J Epidemiol Community Health 1997; 51(5): 479-85.

[64] López-González A, Grases F, Roca P, et al. Phytate (myo-Inositol Hexaphosphate) and risk factors for osteoporosis. J Med Food 2008; 11(4): 747-52.

[65] Alcantara-Martos T, Delgado-Martinez AD, Vega MV, et al. Effect of vitamin $\mathrm{C}$ on fracture healing in elderly osteogenic disorder shiongi rats. J Bone Joint Surg Br 2007; 89(3): 402-7.

[66] Morton D, Barrett-Connor EL, Schneider DL. Vitamin C supplement use and bone mineral density in postmenopausal women. J Bone Miner Res 2001; 16(1): 135-40.

[67] Clements R, Darnell B. Myo-inositol content of common foods: development of a high-myo-inositol diet. Am J Clin Nutr 1980; 33: 1954-67.

[68] Angeloff L, Skoryna SC, Henderson IWD. Effects of the hexahydroxyhexane myoinositol on bone uptake of radiocalcium in rats: Effect of inositol and vitamin $\mathrm{D}_{2}$ on bone uptake of ${ }^{45} \mathrm{Ca}$ in rats. Acta Pharmacol Toxicol (Copenh) 1977; 40(2): 209-15.

[69] Tong B, Barbul A. Cellular and physiological effects of arginine. Mini Rev Med Chem, 2004; 4(8): 823-32.

[70] Howell K, Costello CM, Sands M, Dooley I, McLoughlin P. Larginine promotes angiogenesis in gthe chronically hypoxic lung: a novel mechanism ameliorating pulmonary hypertension. Am J Physiol Lung Cell Mol Physiol 2009; 296: L1042-50.

[71] Soejima K, Klein-Nulend J, Semeins CM, Burger EH. Rapid release of nitric oxide in response to mechanical stress by bone cells grown from adult mouse long bone fragments. In: Goldberg M, Boskey A, Robinson C, Eds. Chemistry and biology of mineralized tissues. Rosemont, IL: American Academy of Orthopedic Surgeons 2000; pp. 287-90.

[72] Corbett S, McCarthy ID, Batten J, Hukkanen M, Polak JM, Hughes SP. Nitric oxide mediated vasoreactivity during fracture repair. Clin Orthop Relat Res 1999; 365: 247-53.
[73] Rajapakse N, Mattson DL. Role of L-arginine in nitric oxide production in health and hypertension. Clin Exp Pharmacol Physiol 2009; 36(3): 249-55

[74] Schulman S, Becker LC, Kass DA, et al. L-arginine therapy in acute myocardial infarction. JAMA 2006; 295(1): 58-64.

[75] Seaborn C, Nielsen FH. Dietary silicon and arginine affect mineral element composition of rat femur and vertebra. Biol Trace Elem Res 2002; 89: 239-50.

[76] National Institutes of Health, Office of Dietary Supplements [Homepage on the Internet]. Zinc: Dietary supplement fact sheet for health professionals. Washington, DC [Updated: $20^{\text {th }}$ Sept 2011 ; Cited: $12^{\text {th }}$ January 2012]. Available from: http://ods.od.nih.gov/fac tsheets/Zinc-HealthProfessional/

[77] Maret W, Sandstead HH. Zinc requirements and the risks and benefits of zinc supplementation. J Trace Elem Med Biol 2006; 20: 3-18.

[78] Guilarte T, Chen MK. Manganese inhibits NMDA receptor channel function: implications to psychiatric and cognitive effects. Neurotoxicology 2007; 28(6): 1147-52.

[79] Bouchard M, Sauvé S, Barbeau B, et al. Intellectual impariment in school-age children exposed to manganese from drinking water. Environ Health Perspect 2011; 119(1): 138-43.

[80] Powers K, Smith-Weller T, Franklin GM, Longstreth WT, Swanson PD, Checkoway H. Parkinson's disease risks associated with dietary iron, manganese and other nutrient intakes. Neurology 2003; 60: 1761-6.

[81] Nielsen S. The biological role of strontium. Bone 2004; 35: 583-8.

[82] Blake G, Fogelman I. Long-term effect of strontium ranelate treatment on BMD. J Bone Miner Res 2005; 20(11): 1901-4.

[83] Blake G, Fogelman I. The correction of BMD measurements for bone strontium content. J Clin Densitom 2007; 10(3): 259-65.

[84] Méar F, Yot P, Cambon M, Ribes M. The characterization of waste cathode-ray tube glass. Waste Manag 2006; 26(12): 1468-76.

[85] Reginster JY, Kaufman JM, Geomaere S, et al. Maintenance of antifracture efficacy over 10 years with strontium ranelate in postmenopausal osteoporosis. Osteoporos Int 2012; 23: 1115-22.

[86] Deeks E, Dhillon S. Strontium Ranelate: a review of its use in the treatment of postmenopausal osteoporosis. Drugs 2010; 70(6): 73359.

[87] Anonymous. Osteoporosis: strontium ranelate has too many adverse side effects. Prescrire Int 2011;20(117): 155

(C) Price et al.; Licensee Bentham Open.

This is an open access article licensed under the terms of the Creative Commons Attribution Non-Commercial License (http://creativecommons.org/licenses/by-nc/3.0/) which permits unrestricted, non-commercial use, distribution and reproduction in any medium, provided the work is properly cited. 